\title{
A influenza invisível \\ a resposta comunitária à pandemia de 1918-1920 no norte rural da Suécia*
}

\author{
Invisible flu \\ community response to the 1918-1920 flu pandemic in the rural \\ areas of north Sweden ${ }^{* *}$
}

\author{
ELISABETH ENGBERG \\ Centro de Estudos de População \\ Base de Dados Demográficos \\ Universidade de Umeå \\ 901 87, Umeå, Suécia \\ elisabeth.engberg@ddb.umu.se
}

RESUMO Ao longo da história humana, pandemias recorrentes de influenza têm afetado indivíduos e sociedades em todo o mundo. No entanto, as respostas sociais têm variado no tempo e no espaço. Este artigo discute a resposta da sociedade à influenza espanhola de 1918-1920 no norte rural da Suécia, focando as medidas tomadas pelas comunidades locais para fazer frente à pandemia que avançava. Nas cinco comunidades rurais estudadas, a resposta oficial foi esparsa e reativa, e a presença da influenza pandêmica é quase invisível nos registros municipais. Medidas preventivas em potencial, tais como o fechamento de escolas e proibições de aglomerações públicas, foram utilizadas inadequadamente e introduzidas tarde demais para que fossem eficazes. Como algumas explicações para a aparente inércia das

\footnotetext{
* Artigo recebido em 09/02/2009. Autor convidado. Texto traduzido do inglês por Erick Ramalho.

** Esta pesquisa é financiada pela Agência Sueca de Gerenciamento de Emergências (a partir de 2009, Agência Civil Sueca de Contingências). Uma versão anterior deste artigo foi apresentada na $33^{a}$ Reunião Anual da Social Science History Association, em 2008, em Miami, Flórida, nos Estados Unidos. Agradeço especialmente a Lucinda Beier, da Illinois State University, e aos meus colegas do Centro de Estudos de População, da Universidade de Umeå, pelos comentários construtivos e pelos conselhos de grande auxílio.
} 
autoridades locais durante a influenza espanhola sugerem-se a luta, então corrente, contra as privações de uma época de guerra, a crise de alimentos somada a uma economia tensa, uma insuficiente administração pública de saúde, uma política pública nacional preventiva que almejava primordialmente à prevenção da cólera e o uso continuado de métodos tradicionais para se lidar com crise na sociedade.

Palavras-chave influenza pandêmica, resposta social, áreas rurais

ABSTRACT Throughout human history, recurrent influenza pandemics have affected individuals and societies all over the world. Yet the social responses have varied with time and space. This article discusses society's response to the Spanish influenza of 1918-1920 in northern rural Sweden, focusing on measures taken by local communities to meet the advancing pandemic. In the five studied rural communities, the official response was sparse and reactive, and the presence of pandemic influenza is almost invisible in the municipal records. Potentially preventive measures, such as school closures and bans on public gatherings, were used inadequately and introduced far too late to be effective. The current struggle with wartime hardship, food crisis and a strained economy, an insufficient public health administration, a national preventive policy primarily aimed at the prevention of cholera, and the continued use of traditional methods to deal with crises in society are suggested as some explanations for local authorities' apparent inertia during the Spanish influenza.

Keywords pandemic influenza, social response, rural areas

\section{Introdução}

Uma perspectiva urbana tem há muito dominado a pesquisa sobre a resposta da sociedade à pandemia de influenza de 1918 a $1920 .{ }^{1}$ As experiências em grandes cidades norte-americanas são particularmente bem documentadas, e estudos recentes têm revelado que comunidades que estão aptas a organizar medidas efetivas de saúde pública tiveram, com o passar do tempo, uma experiência menos severa do que aquelas que de-

1 Ver cf. CROSBY, Alfred. America's forgotten pandemic: the influenza of 1918. [Epidemic and Peace, 1918.] Cambridge: Cambridge University Press [1976], 1989; JOHNSON, Niall. Britain and the 1918-19 influenza pandemic: a dark epilogue. London: Routledge, 2006, p.116-151; VAN HARTESVELDT, Fred R. The 1918-1919 pandemic of influenza: the urban impact in the Western World. Lewiston: Edwin Mellen Press, 1992; TOMKINS, Sandra M. The failure of expertise: public health policy in Britain during the 1918-19 influenza epidemic. Social History of Medicine, v.5, n.3, p.435-54, 1992; JONES, Essylt W. Influenza 1918: disease, death and struggle in Winnipeg. Toronto: University of Toronto Press, 2007. 
moraram a implementar ações ou que não implementaram nenhuma ação. ${ }^{2}$ Consideravelmente, sabe-se menos sobre o que aconteceu em áreas com uma administração da saúde pública menos desenvolvida e diferentemente organizada do que sobre o que existia nessas cidades maiores. Embora as árduas conseqüências relativamente às populações locais em diferentes partes do mundo tenham atraído grande atenção em pesquisas recentes, a resposta social à pandemia de 1918 a 1920 nas áreas rurais tradicionais é ainda um tópico quase ignorado no amplo corpus da literatura que lida com a influenza espanhola. ${ }^{3}$ Este estudo objetiva direcionar a atenção à resposta da sociedade à influenza pandêmica em cinco freguesias ${ }^{4}$ em uma região esparsamente povoada do norte da Suécia, país onde, àquela época, mais de $70 \%$ da população viviam no campo e tiravam sua sobrevivência principalmente da agricultura. ${ }^{5}$ Como na maioria das áreas rurais, particularmente no norte, o número de médicos era pequeno, a disponibilidade de cuidado médico era limitada e a administração da saúde pública funcionava em nível muito elementar. ${ }^{6}$ Nessas cinco freguesias - Skellefteå, Byske, Bureå, Burträsk e Jörn - pouquíssimas medidas oficiais foram tomadas a fim de lidar com a pandemia que avançava, e esta, de maneira surpreendente, deixou poucos traços nos registros municipais. Tentar entender por que aquilo que seria esperado não ocorre pode ser evasivo, mas, admitindo essas dificuldades, o presente artigo busca, contudo, achar explicações para o surpreendente silêncio nessas freguesias rurais setentrionais. ${ }^{7}$ Considerando que decisões locais poderiam ter sido influenciadas por fatores externos ao contexto local, certa atenção também será dada às respostas das autoridades nacional e regional à pandemia, bem como ao contexto socio-econômico particular na Suécia proximamente à eclosão da influenza espanhola.

2 MARKEL, Howard; LIPMAN, Harvey B. et alli. Nonpharmaceutical interventions implemented by US cities during the 1918-1919 influenza pandemic. JAMA, v.298, n.2, p.644-54, 2007; BOOTAMS, Martin C.J. and FERGUSON, Neil M. The effect of public health measures on the 1918 influenza pandemic in U.S. cities. PNAS v.104, n. 18, p.758893, 2007; HATCHETT, Richard J.; MECHER, Carter E.; LIPSITCH, Mark. Public health interventions and epidemic intensity during the 1918 influenza pandemic. PNAS, n.104, p.7313-14, 2007.

3 Algumas exceções encontram-se em: ECHENBERG, Myron. 'The dog that did not bark': memory and the 1918 influenza epidemic in Senegal. In: PHILLIPS, Howard and KILLINGRAY David. (eds.) The Spanish influenza pandemic of 1918-19: new perspectives. London: Routledge, 2003, p.230-238; MCSWEENY, Kirsten et alli. Was rurality protective in the 1918 influenza pandemic in New Zealand? The New Zealand Medical Journal, v.120, n.1256, 2007; AFKHAMI, Amir. Compromised constitutions: the Iranian experience with the 1918 influenza pandemic. Bulletin of the History of Medicine, v.77, n.2, p.367-392, 2003.

4 O termo freguesia, assim como em Portugal, designa a menor divisão administrativa de províncias e cidades. (Nota do tradutor).

5 Historisk statistik för Sverige, parte 1, população em 1720-1950. Örebro: Statistiska centralbyrån 1969, tab.4, p.47.

6 EDVINSSON Sören. Den osunda staden. Umeå: Base de Dados Demográficos, 1992, p.78. Ver também Relatório Anual de 1918, Oficial Chefe de Saúde [doravante OCS] de Västerbotten. Umeå: AB Västerbottens Nyheters Tryckeri, 1919, p.62.

7 C.f. ECHENBERG, Myron. 'The dog that did not bark', p.230. 


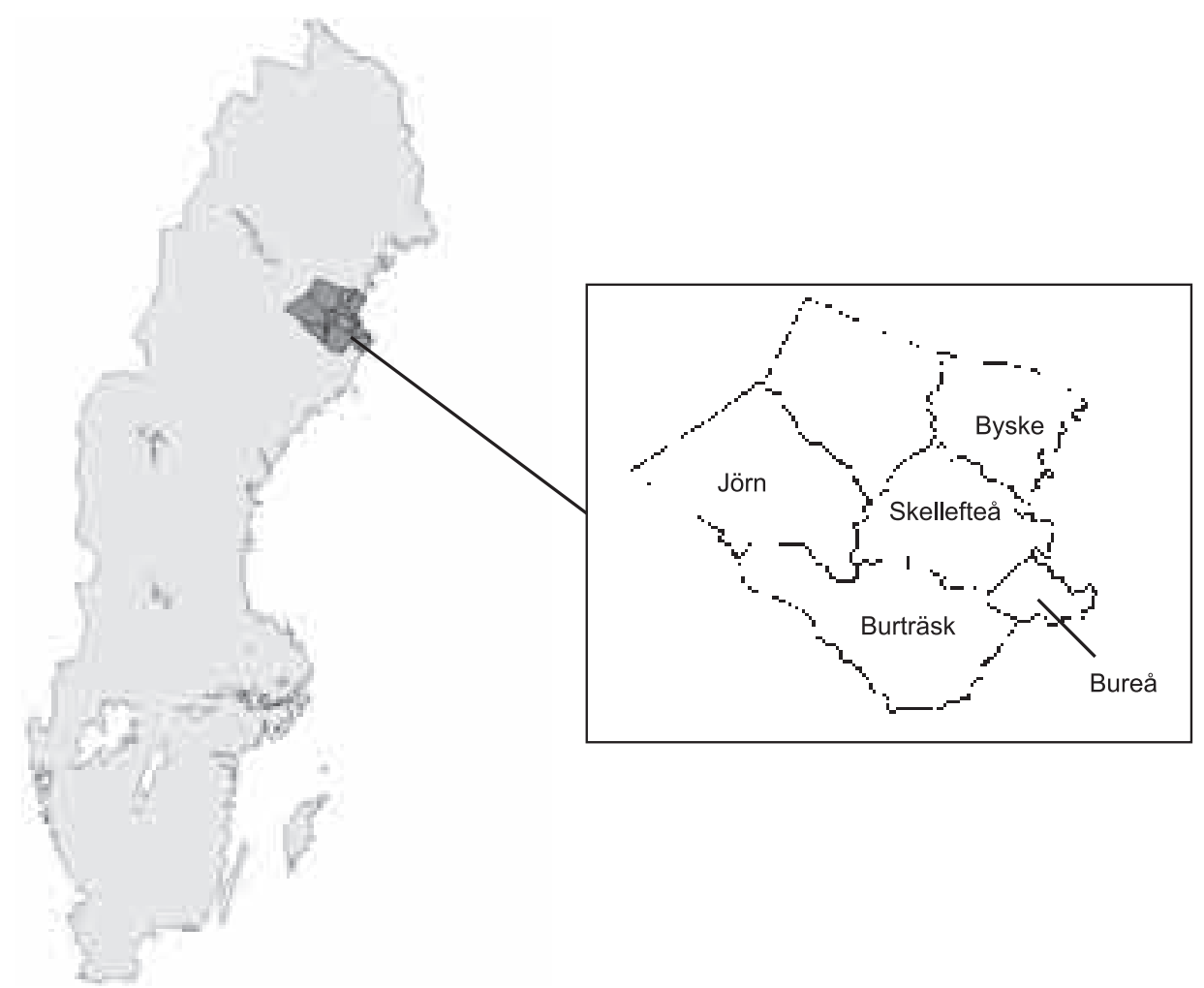

Figura 1: A região de Skellefteå, no norte da Suécia.

Fonte: Base de Dados Demográficos, Universidade de Umeå.

Povoadas de maneira ampla e esparsa e com a agricultura e a silvicultura a dominar-lhes as economias, essas freguesias eram bem típicas da situação no norte rural. A indústria e o comércio, todavia, cresciam, ainda que lentamente, em particular na região costeira. Em Bureå havia uma fábrica de sulfito, e tanto Byske quanto Bureå possuíam grandes serrarias. Skellefteå era a freguesia maior, com uma área de cerca de $2.000 \mathrm{~km}^{2} \mathrm{e}$ uma população de cerca de 20.000 habitantes. Burträsk e a freguesia interiorana de Jörn eram ainda mais esparsamente povoadas, com 9.000 e 5.000 indivíduos, respectivamente, sobre uma área que é, aproximadamente, como a de Skellefteå. Em Byske havia 9.000 indivíduos sobre 1.000 km², enquanto Bureå, que havia recentemente se separado de Skellefteå, era a freguesia mais densamente povoada, com uma população de cerca de 5.000 habitantes sobre $300 \mathrm{~km}^{2} .{ }^{8} \mathrm{Em} \mathrm{1918}$, todas as freguesias constituíam

8 Demographic Data Base. Umeå University; Nordisk Familjebok. Stockholm: Nordisk Familjeboks förlag, 1917; SJÖGREN, Otto. Sverige: Geografisk, topografisk, statistisk beskrifning. Stockholm: Wahlström \& Widstrand, part IV, 1924. 
distritos médicos separados, e estes eram governados pelos Oficiais de Saúde Distritais (provinsialläkare), médicos que, além de seu trabalho com pacientes, tinham também certas obrigações administrativas e de supervisão. ${ }^{9}$ Em todos os distritos, com exceção de Skellefteå, esses eram também os únicos médicos a atender a população.

\section{A pandemia de influenza de 1918 a 1920 na Suécia}

É bastante incomum encontrar alguém que não tenha sido acometido pela influenza espanhola. ${ }^{10}$

A gripe espanhola chegou à Suécia no final de junho de 1918, quando foram relatados casos na província de Scania, no sul. ${ }^{11}$ Apenas algumas semanas depois, a influenza epidêmica espalhou-se por todas as partes do país. Exatamente como em muitos outros contextos, a doença parecia desenvolver-se entre as forças armadas, e os jornais suecos logo se encheram de relatos sobre um grande número de indivíduos acometidos pela doença nas unidades militares. ${ }^{12} \mathrm{Na}$ condição de nação neutra, a Suécia não estava diretamente envolvida nos conflitos armados, porém os regimentos estavam repletos de homens em conseqüência da mobilização da época de guerra. Por isso, a influenza espalhou-se rapidamente dentre os jovens confinados nos quartéis militares lotados. ${ }^{13} \mathrm{~A}$ primeira morte por causa da doença foi relatada em Gotemburgo, em julho. Nesse estágio inicial, nada parecia indicar que aquilo fosse algo diferente de um surto, "corriqueiro" tão-somente, de influenza pandêmica. A partir de experiências vividas com a influenza russa em 1889 e 1890, sabia-se que mortes podiam ser esperadas, e, até então, a taxa de mortalidade não era alarmante. ${ }^{14}$ Potencialmente preocupante, contudo, era o fato de que um grande número de mortes pela influenza havia acontecido entre jovens, tanto homens como mulheres. ${ }^{15}$ Esta era uma característica que se distinguia em comparação à pandemia de influenza de 1889-1890, a qual se comprovou particularmente letal para os idosos e para quem já se encontrava frágil. ${ }^{16}$

9 Relatório Anual de 1918, OCS de Västerbotten, p.35. Deve-se notar, contudo, que até 1920, Bureå era oficialmente um distrito médico "extra" e não possuía um Oficial de Saúde Distrital que estivesse ali permanentemente designado. Até então, as estatísticas relativas a Bureå incluíam-se junto às do distrito de Skellefteå.

10 Relatório Anual de 1918, OCS de Västerbotten, p.61.

11 O relato da pandemia de influenza de 1918-1920 na Suécia baseia-se em grande parte em ÅMAN, Margareta. Spanska sjukan: den svenska epidemin 1918-1920 och dess internationella bakgrund. Uppsala: Almquist \& Wiksell, 1990.

12 ÅMAN, Margareta. Spanska sjukan, p.42-44

13 ÅMAN, Margareta. Spanska sjukan, p.85-109

14 ENGBERG, Elisabeth. A true pandemic: the Russian influenza in Sweden 1889-1890 through the eyes of local medical officers. Chicago/USA: 32a Reunião Anual da SSHA, 2007. (Comunicação não publicada).

15 ÅMAN, Margareta. Spanska sjukan, p.45.

16 ENGBERG, Elisabeth. A true pandemic. 


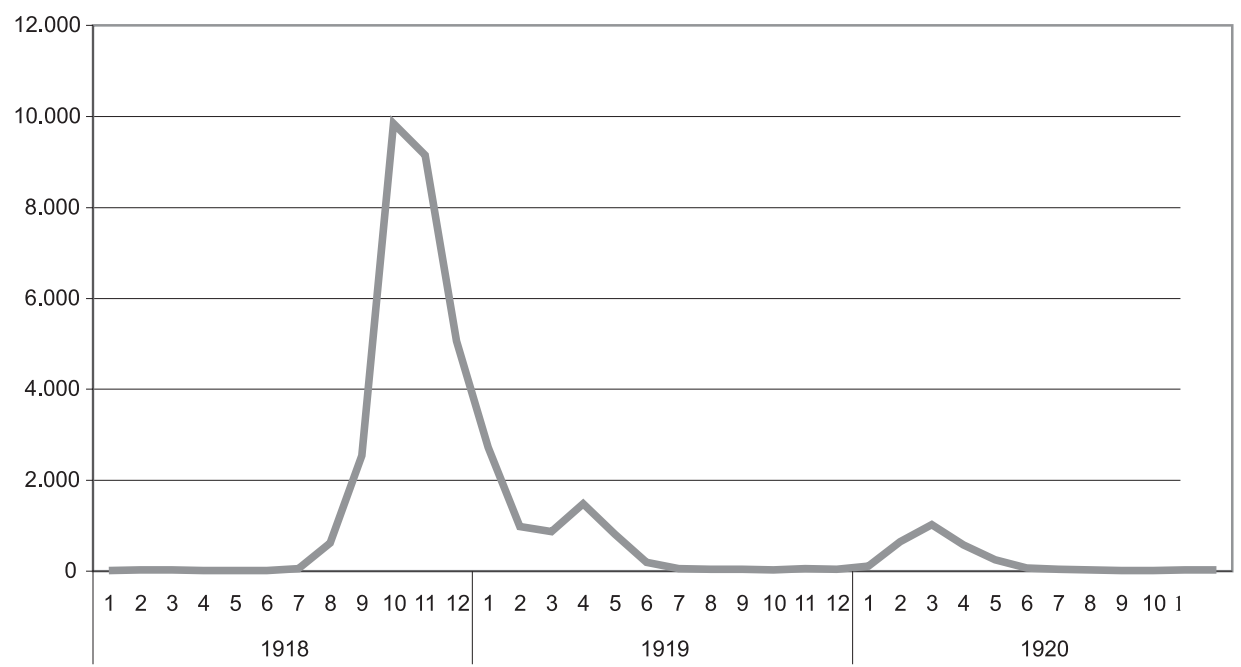

Figura 2

Fonte: Margareta Åman, Spanska sjukan: den svenska epidemin 1918-1920 och dess internationella bakgrund. Uppsala, 1990, p.65.

Ao final de agosto de 1918, um segundo e virulento surto da doença havia se iniciado, e estava claro que se tratava de algo muito mais sério do que os encontros anteriores com a influenza. A doença tomara um curso sem precedentes e mais grave, e seus estágios seguiram aquilo que hoje reconhecemos como um padrão bem determinado. ${ }^{17}$ Ao longo das semanas seguintes de setembro, a morbidade e a mortalidade cresceram dramaticamente até alcançar seu pico por volta de outubro/novembro, seguidas por uma diminuição que se distingue em dezembro (Figura 2). Ao todo, 27.379 mortes foram relatadas na Suécia ao longo de 1918, sendo a mortalidade mais elevada na faixa etária de 20-40 anos (Figura 3).$^{18}$ Assim, também na Suécia estava presente esse padrão de mortalidade em formato de "W", que vem a ser uma característica distintiva dessa pandemia.

A pandemia continuou a florescer em 1919, porém com intensidade consideravelmente mais baixa do que no ano anterior. Ao todo, 7.341 casos letais foram relatados em 1919, a maioria dos quais entre janeiro e março. ${ }^{19}$ No entanto, nem tudo estava acabado. Em fevereiro de 1920, o país foi atingido por uma quarta onda severa, que foi especialmente desastrosa para as áreas esparsamente povoadas a noroeste, onde uma grande parte da população havia escapado dos surtos anteriores. Em Arjeplog, uma

17 ÅMAN, Margareta. Spanska sjukan, p.45ff. O curso geral da doença é descrito em MAMELUND, Svenn-Erik. Influenza, historical. In: HEGGENHOUGEN, K. and QUAH, S. (eds.) International Encyclopedia of Public Health. Amsterdam: Elsevier, 2008, v.3, p.601-602.

18 ÅMAN, Margareta. Spanska sjukan, p.67.

19 ÅMAN, Margareta. Spanska sjukan, p.67. 
pequena freguesia nas montanhas próximas à fronteira com a Noruega, quase $3 \%$ da população (27/1.000) morreu ao longo de algumas semanas desastrosas de fevereiro, em 1920. ${ }^{20}$

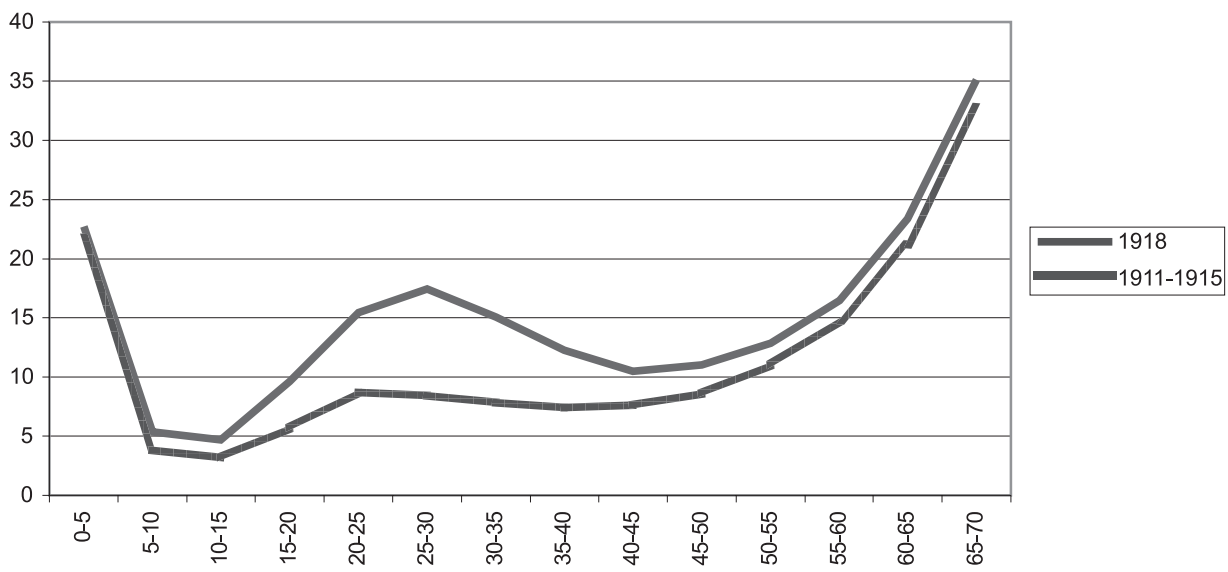

Figura 3

Fonte: Sveriges officiella statistik (SOS), Hälso- och Sjukvård, 1927.

Os dados de morbidade para a influenza espanhola na Suécia estão disponíveis nas estatísticas nacionais e totalizam 516.013 casos ao ano de 1918, o que corresponde a cerca de 9\% da população. ${ }^{21}$ Como sempre acontece com a influenza, os números oficiais refletem apenas os casos notificados e, portanto, oferecem uma imagem distorcida da realidade. $\mathrm{Na}$ realidade, aqueles episódios que foram levados aos médicos estavam longe de serem todos os episódios de influenza. "Não se consulta um médico no campo por conta de alguns dias de febre mais dor de cabeça, dor nas costas e nos membros", observou um Oficial de Saúde Distrital daquele lugar durante a última pandemia de influenza de 1889-1890, e não há razão para crer que esta atitude mudara muito desde então, ao menos nas áreas rurais. ${ }^{22} \mathrm{~A}$ disponibilidade limitada de cuidados médicos, particularmente nas partes setentrionais do país, muito provavelmente contribuiu para que o registro dos casos de influenza estivesse incompleto. "O número de cargos vagos cresce a cada ano (...). Grandes partes do país ficam sem a opção de chamar um médico em caso da doença", observa com resignação o

20 ÅMAN, Margareta. Spanska sjukan, p.142. Ver também ÖHMAN, Lennart. Hur sjukvården kom till norr. Arvidsjaur: Loanna förlag, 1987, p.257-272.

21 ÅMAN, Margareta. Spanska sjukan, p.59

22 ENGBERG Elisabeth. A true pandemic; Base de Dados de História Médica (BDHM), Linköping University; Relatório Anual de 1889, OSD de Vänersborg. 
Oficial Chefe de Saúde de Västerbotten, em seu Relatório Anual, em 1918.23 Relativamente a esse período, até mesmo o número de casos notificados deve ser considerado com cuidado, porque a carga de trabalho pesada durante a pandemia de influenza espanhola tornou impossível para muitos médicos manter em dia o trabalho burocrático. "Os médicos nem tinham tempo nem possibilidade de tomar notas sobre cada caso individualmente", comenta ele novamente acerca deste tópico, no início de 1919. ${ }^{24}$

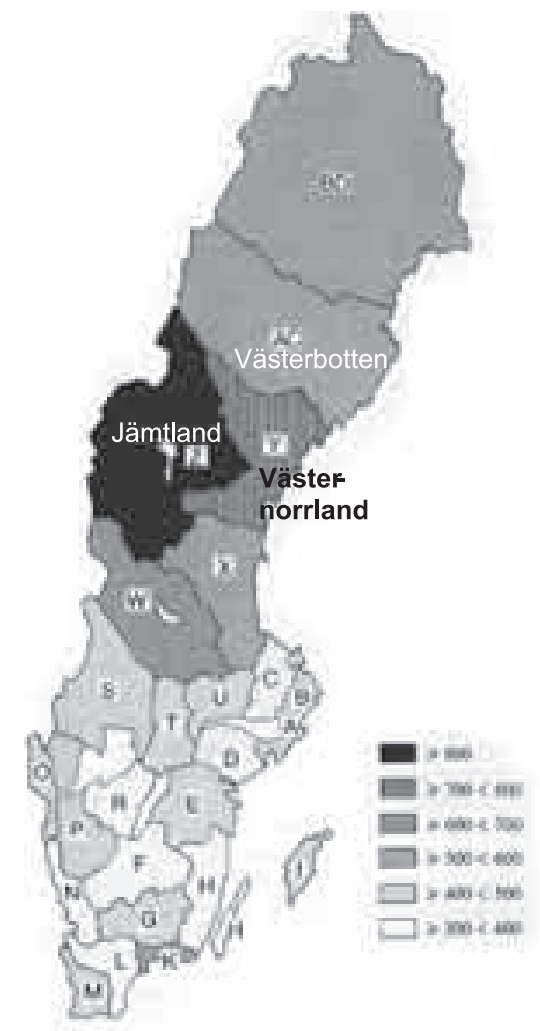

Figura 4: Mortalidade (por 100.000) por influenza na Suécia, em 1918; distribuição por províncias.

Fonte: ÅMAN, Margareta. Spanska sjukan, p.74.

De agosto de 1918 em diante, boletins das províncias do norte tornaram-se freqüentes nos jornais, e era como se as partes setentrionais da Suécia estivessem mais gravemente acometidas pela doença do que o sul. ${ }^{25}$

23 Relatório Anual de 1918, OCS de Västerbotten, p.7.

24 Estocolmo. Arquivo Nacional. Arquivo da Diretoria Nacional de Medicina. (ADNM). Influensabyrån, relatórios especiais de 1918, Ell:2, OCS de Västerbotten.

25 ÅMAN, Margareta. Spanska sjukan, p.45ff, 75. 
Depois, isso também se verificou nas estatísticas nacionais (Figura 4). A província rural de Jämtland (Z), lar de dois grandes regimentos militares, apresentava a mortalidade mais elevada em 1918, seguida de perto pela província industrializada de Västernorrland (Y). A província de Västerbotten (AC), onde se situam Skellefteå, Byske, Bureå, Burträsk e Jörn, também apresentava elevados índices de mortalidade em comparação a muitas outras províncias do país. ${ }^{26}$

\section{Uma época de crise}

É por isso que as pessoas estavam fazendo filas; filas por comida - por pão, farinha, batatas e manteiga - bem, por tudo que era possível comer. As pessoas estavam implorando por comida - roubando comida - comprando comida no mercado negro, se tivessem algum dinheiro para comprar. ${ }^{27}$

Quando a influenza espanhola alcançou a Suécia, em junho de 1918, encontrou uma sociedade que já se afligia com privações: a economia de uma época de guerra em que a luta por comida e por sobrevivência vinha sendo parte integral da vida diária para quase todos ao longo de diversos anos, e em quase todos os níveis da sociedade. O fato de que a Suécia não estava diretamente envolvida nos confrontos armados não significa que o país não tivesse sido afetado pelos rompimentos das épocas de guerra. Antes da guerra, a Suécia havia se beneficiado de sua considerável exportação de carne e de laticínios. Ao mesmo tempo, havia a necessidade de considerável importação de outros alimentos básicos, tais como cereais, margarina, café e especiarias. Um terço do consumo anual de grãos, por exemplo, era importado da Alemanha, da Dinamarca e da Rússia. ${ }^{28}$ Quando a guerra foi deflagrada, em 1914, nenhuma medida em particular foi tomada pelo governo sueco para assegurar o suprimento de alimentos. A opinião geral era de que as hostilidades logo se findariam, e as autoridades responsáveis não viram necessidade para racionar alimentos ou para estocar suprimentos para o futuro. Isto logo se comprovaria como sendo um grande erro, e em 1916 o país deparava-se com uma clara escassez de alimentos. A colheita de verão fora mais fraca do que o usual, os preços dos alimentos estavam em geral subindo e importar grãos tornou-se cada vez mais difícil. No nível nacional, um novo departamento público, a Agência Nacional para Economizar (ANE) foi criada para assegurar e controlar

26 ÅMAN, Margareta. Spanska sjukan, p.73.

27 Ver as memórias de uma idosa sobre sua infância em 1914-1918, na Suécia: INGELS, Birgit. Fabian med tumnageln. In: DE LAVAL, Märta. (ed.) Så minns jag 10-talet. Stockholm: Proprius, 1971, p.101.

28 HIRDMAN, Yvonne. Magfrågan: mat som mål och medel, Stockholm 1870-1920. Stockholm: Rabén \& Sjögren, 1983, p.209ff. 
o suprimento nacional de alimentos. Além de numerosas subdivisões, três Diretorias Regionais de Suprimento de Alimentos e mais de 2.500 Comitês de Distribuição de Alimentos locais encontravam-se também sob a jurisdição desse enorme corpo administrativo. Por meio do racionamento, uma política austera de regulação de preços e a distribuição supervisionada de alimentos em nível local, a ANE tentou lidar com a crise, que se tornava cada vez mais grave. Racionou-se açúcar em 1916 e, a partir de 1917, também o pão e os grãos. ${ }^{29}$

Em pouco tempo, a situação deteriorou-se ainda mais, quando o bloqueio naval aliado da Alemanha tornou praticamente impossíveis todas as importações. ${ }^{30}$ Havia também a crescente inquietação social que se originava da insatisfação disseminada em relação ao modo pelo qual o governo liberal lidara com a crise até aquela data. Ao longo de algumas semanas, em abril de 1917, o ano da revolução, manifestações e tumultos ocorreram em todo o país quando pessoas famintas das classes trabaIhadoras exigiam pão, aumento de salário e mudança política. ${ }^{31}$ Algumas declarações ouvidas nas passeatas antecipavam a inevitabilidade de uma violenta sublevação e deixavam explícitas as referências aos eventos que estavam acontecendo na Rússia:

Se a chibata da fome continuar a gemer sobre nós e nossos filhos, não poderemos, a longo prazo, ser considerados responsáveis pelas ações que serão tomadas. Há exemplos por parte de nosso vizinho do leste de que ações de força podem abolir a escassez de alimentos. Este governo tem de chegar ao seu fim..$^{32}$

Em 1918, o ano da influenza espanhola, a situação no país estava muito difícil. As medidas tomadas pelo governo, em seus esforços para lidar com a crise de alimentos, comprovaram-se ineficientes e burocráticas, a despeito de esforços abrangentes, em nível local, para fornecer alimentos para distribuição aos necessitados. A política nacional de regulação de preços forçava os produtores à venda a preços comparativamente baixos, o que tornou muitos fazendeiros mais inclinados a usar os grãos para o consumo próprio do que a vendê-los para comitês locais de distribuição de alimentos. O mercado negro prosperava, e os preços dos alimentos subiam ainda mais para todos aqueles que não tinham o direito ao auxílio. Particularmente difícil era a situação das cidades. ${ }^{33}$

29 ANDRAE, Carl Göran. Revolt eller reform: Sverige inför revolutionerna i Europa 1917-1918. Stockholm: Carlsson, 1998, p.20-22; HIRDMAN, Yvonne. Magfrågan, p.211-212.

30 HIRDMAN, Yvonne. Magfrågan, p.210; HILDEBRAND, Karl. De svenska statAMSkterna och krigstidens folkhushållning. Stockholm: Nordstedt, 1916, p.1-6.

31 ANDRAE, Carl Göran. Revolt eller reform, p.23-29, 46-82.

32 Declaração ouvida durante uma passeata em Borlänge, em 1917, na qual mulheres casadas com trabalhadores ferroviários criticavam a inabilidade das autoridades em lidar com a crise. Citado em: ANDRAE, Carl Göran. Revolt eller reform, p.30.

33 HIRDMAN, Yvonne. Magfrågan, p.215-254. 


\section{Cinco freguesias acometidas}

Ao longo da última metade do ano a influenza espanhola apareceu com uma força que não tem paralelos na memória da geração mais jovem. ${ }^{34}$

Em 1889, a última vez em que uma grande pandemia de influenza apareceu na Suécia, pouquíssimos médicos estavam familiarizados com a doença por experiência própria. ${ }^{35} \mathrm{Em}$ sua forma pandêmica, a influenza estivera ausente por tanto tempo, que quase havia sido esquecida tanto pelos pacientes quanto pelos clínicos. Este não foi o caso em 1918. Ao longo dos 30 anos anteriores, epidemias sazonais recorrentes fizeram com que tanto os médicos quanto o povo estivessem familiarizados com a doença. Na província de Västerbotten (Figura 3), há registros de surtos em 1914, 1915 e 1916, bem como em 1917.36 "Ao longo da primeira metade do ano, parecia que a influenza estava finalmente cedendo após diversos anos de devastação", observa o Oficial Chefe de Saúde de Västerbotten, Dr. Forssman, em seu relatório anual, em 1918. ${ }^{37}$ Infelizmente, ele não estava correto. Em julho de 1918 apareceram os primeiros casos, em agosto a pandemia estava "por toda parte" e, iniciando-se em algum momento entre o final de setembro e o início de outubro, a virulenta segunda onda teve a província sob suas garras. "Em algumas vilas, não havia uma única pessoa saudável que fosse capaz de cuidar dos afazeres domésticos necessários", continua o Dr. Forssman, mais à frente em seu relatório. ${ }^{38}$

Embora as estatísticas oficiais sobre taxas da doença para esse período sejam certamente subestimações consideráveis, os dados disponíveis podem, contudo, nos dar uma idéia aproximada da virada dramática que ocorreu ao longo do último quarto daquele ano. A figura 5 mostra que em Skellefteå, Byske, Burträsk e Jörn, bem como na província, o número de casos relatados cresceu rapidamente ao longo de outubro e novembro de 1918. Byske e Burträsk destacam-se como os distritos mais acometidos pela doença, mas com referência à discussão anterior acerca dos grandes problemas associados com os dados de morbidade, deve-se considerar com muita cautela as diferenças observadas. Pode-se notar, todavia, que Byske e Burträsk foram dois dos quatro distritos sem postos vagos da província que receberam assistência médica extra durante a pandemia. ${ }^{39}$ Isto sugere que a situação era considerada como extremamente difícil, particularmente

34 Relatório Anual de 1918, OCS de Västerbotten, p.46

35 ENGBERG Elisabeth. A true pandemic.

36 Relatórios Anuais 1914, 1915, 1916 e 1917, OCS de Västerbotten.

37 Relatório Anual de 1918, OCS de Västerbotten, p.46.

38 Relatório Anual de 1918, OCS de Västerbotten, p.61.

39 Härnösand. Arquivo Regional de Härnösand. ACA, Decretos da RDM 1908-1921 DIlp:3, Dnr.112/62, 112/64, $110 / 45$. 
tendo como pano de fundo a escassez de pessoal médico no país, nessa época. ${ }^{40} \mathrm{O}$ Oficial de Saúde Distrital de Burträsk comenta abertamente as estatísticas para este distrito: "913 pessoas buscaram assistência médica, mas é provável que pelo menos 6.000 ou 7.000 dos 9.445 habitantes do distrito tenham sido branda ou mais gravemente acometidos pela doença" ${ }^{41}$ Não há razão por que a situação devesse ter sido diferente em outras freguesias da mesma região.

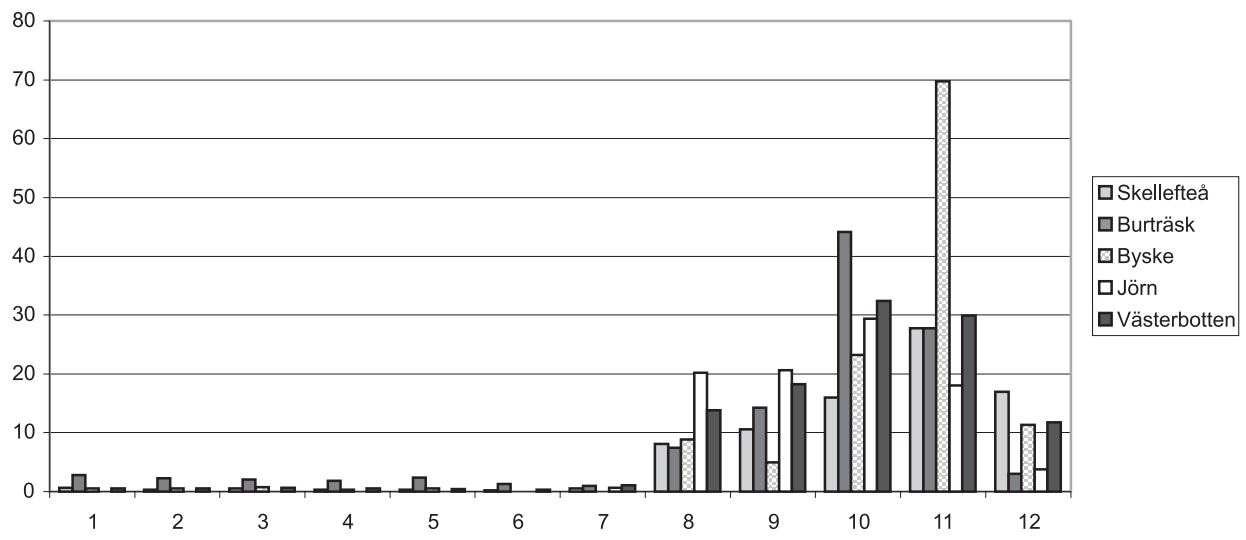

Figura 5

Fonte: Relatório Anual de 1918, médico oficial chefe de saúde, Västerbotten. (Note-se que, na estatística agregada, incluem-se os dados relativos a Bureå no distrito de Skellefteå).

Os dados de mortalidade anual para esse período também testemunham o fato de que nenhuma dessas freguesias escapou dos tormentos da influenza espanhola em 1918. Infelizmente, somente números para todas as causas de morte estão disponíveis nas estatísticas oficiais, mas também esses dados em estado bruto contam sua história. Skellefteå, com a população maior, seguia aproximadamente o mesmo padrão da província, Västerbotten, que em 1918 tinha a quarta mais elevada mortalidade por influenza na Suécia: 598/100.000 habitantes. ${ }^{42}$

40 Arquivo Regional de Härnösand. Arquivo da Administração do Condado [Landskansliet] Västerbotten. ACA, Cartas da Real Diretoria de Medicina, Dllt:4, Cable Oct 8, 1918, Dnr 111/55.

41 Umeå. Administração de Saúde do Condado. Arquivo da Administração do Condado. (AAD) [Landskansliet] Västerbotten, Burträsk sjukstugas arkiv, B1:1, Relatório Anual do OSD de 1918.

42 ÅMAN, Margareta. Spanska sjukan, p.73. A mortalidade por influenza não era classificada separadamente nas tabelas para os distritos rurais, mas apenas para as cidades. Contudo, esses números não são muito representativos para Västerbotten, onde 95\% da população vivia em áreas rurais. Em 1918, a população nas duas cidades era de 7.000 e 2.700, respectivamente, em comparação a cerca de 175.000 no campo. 


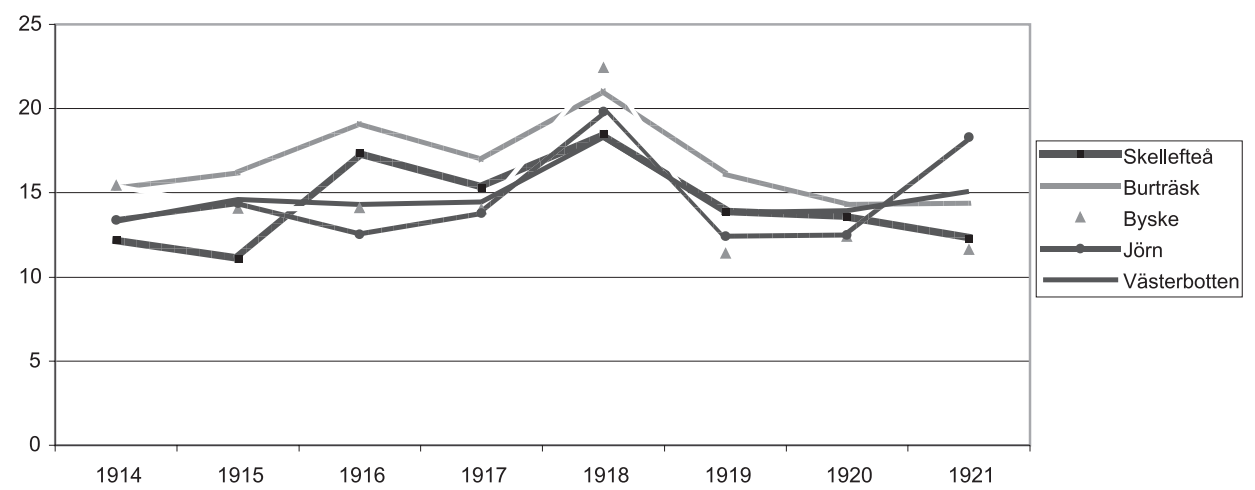

Figura 6

Fonte: Relatório Anual de 1918, médico oficial chefe de saúde, Västerbotten (Inclui-se Bureå no distrito de Skellefteå).

Ainda em termos de mortalidade, Byske e Burträsk destacam-se como os distritos mais gravemente acometidos pela influenza em 1918, mas Jörn também mostra níveis de mortalidade mais altos que a província. Nessas cinco freguesias, como em numerosas outras comunidades ao redor do mundo, o fardo, já pesado, provocado pelo sofrimento dos tempos de guerra foi incrementado pela morbidade disseminada, uma mortalidade notadamente aumentada e óbitos imprevistos em grupos etários nos quais a morte não era esperada. As circunstâncias eram sem dúvida extraordinárias, porém provocaram alguma reação da sociedade oficial?

\section{Aconselhamento ambíguo}

Embora a Suécia tivesse uma legislação bem elaborada para a saúde pública e o controle de doenças, a legislação não estipulava muitas recomendações sobre o que fazer na eventualidade de um surto de influenza pandêmica. ${ }^{43}$ Promulgada em 1874 e 1875, a legislação então vigente ainda via o cólera como a maior ameaça epidêmica. De um ponto de vista estritamente legal, a influenza não era sequer categorizada como doença epidêmica, pois não se a mencionava no catálogo de doenças epidêmicas que requeriam medidas específicas a serem tomadas para proteger a sociedade: cólera, varíola, tifo, febre tifóide, febre escarlate, difteria e disenteria. ${ }^{44}$ Ademais, isolamento, quarentena, desinfecção, vigilância de fronteira e inspeções de navios - as medidas legais propostas para o controle de

43 SFS 1874:68, Kongl. Maj:ts nådiga Helsowårdsstadga för riket [Ato de Saúde Pública]; SFS 1875:21 Kongl. Maj: ts nådiga Förordning angående åtgärder mot införande och utbredning af smittosamma sjukdomar bland rikets invånare [Ato de Controle de Doenças]. Uma nova política pública relativa a Saúde Pública e Controle de Doenças foi promulgada em 1919, mas não foi cumprida até primeiro de janeiro de 1920.

44 SFS 1875:21, § 20. 
doenças que visavam principalmente a moléstias como a cólera e a difteria - nem sempre se adequavam bem ao controle de uma epidemia com uma difusão tão rápida e descontrolada como a influenza.

Quando a sociedade era atingida por uma epidemia, eram primordialmente os atores em nível local que deviam reagir: as Diretorias Municipais, os Comitês Executivos de Municípios, os Comitês de Saúde Pública, bem como o Oficial de Saúde Distrital do distrito atingido. ${ }^{45}$ Um fato importante de ser considerado é o de que cidades e áreas rurais possuíam, nessa época, organizações de saúde pública diferentes. Como resultado de um movimento do século XIX pela saúde pública, as cidades estavam em geral mais bem organizadas, com Comitês de Saúde Pública obrigatórios dos quais os Oficiais de Saúde Distritais eram membros ex officio. A partir de 1850, na Suécia, grande interesse foi dispensado ao precário padrão de saúde entre as classes mais baixas e à necessidade de melhorias sanitárias nas cidades insalubres. No entanto, nas áreas rurais, que eram em geral consideradas mais salubres, o chamado para a reforma de saúde pública não recebeu atenção na mesma proporção. ${ }^{46} \mathrm{Em} 1918$, era ainda o Comitê Executivo Municipal que lidava com as questões de saúde ao lado de assuntos de bem-estar social e quase qualquer outro assunto de interesse municipal. Por isso, uma grande responsabilidade recaia sobre os Oficiais de Saúde Distritais, especialmente durante uma pandemia. Além de seu dever de notificar todos os novos casos, de aconselhar administradores leigos nos comitês municipais acerca do que deveria ser feito para evitar a disseminação da doença, de pôr em prática o controle da doença e de escrever relatórios detalhados, eles também tinham que cuidar dos doentes. ${ }^{47}$ Os comitês municipais, por outro lado, eram responsáveis por fornecer recursos suficientes para as medidas necessárias e - se preciso - por tomar a iniciativa de fechar escolas e evitar aglomerações desnecessárias. Quanto ao resto, eles deveriam seguir as instruções fornecidas pelo médico local. ${ }^{48} \mathrm{~A}$ estrutura oficial era elaborada e detalhada, mas, ainda assim, não ficava claro como, em que ordem e por quem as coisas deveriam ser feitas. Uma razão é que as regulamentações relativas às doenças epidêmicas são encontradas tanto no Ato de Saúde Pública quanto no Ato de Controle de Doenças. Os dois atos sobrepõem-se, porém não são inteiramente correspondentes, o que dá margem a diferentes leituras. Quando a sociedade era atingida por uma epidemia, as autoridades regionais da província também tinham certas responsabilidades legais relativas à tomada de ações. Todavia, isto se restringia à promulgação de decretos e regulamentações públicas,

45 SFS 1874:68, § 32-36.

46 EDVINSSON, Sören. Den osunda staden, p.71-80.

47 SFS 1875:21, § 24.

48 SFS 1874:68, § 34-36 
quando se considerava necessário evitar a disseminação de doenças, bem como à coordenação e à redistribuição de recursos médicos disponíveis pelas áreas afetadas. ${ }^{49}$

Não foi apenas a legislação que falhou em prover instruções claras sobre como lidar com a eclosão da pandemia de influenza em 1918. Na Suécia, como em muitos outros países, havia a falta de consenso dentro da comunidade científica relativamente ao que poderia e deveria ser feito durante uma pandemia dessa magnitude. Uma facção da classe médica proclamava que a intervenção e a prevenção eram a solução. Influenciados pela bacteriologia moderna, eles argumentavam que, evitando-se os focos de infecção e pondo em prática a higiene e o isolamento, poder-se-ia retardar a disseminação acelerada da doença. Outros estavam céticos quanto a qualquer tipo de intervenção, tendo como argumento que o caráter extremamente contagioso da influenza tornava inúteis todas as tentativas de prevenção. A interferência na vida cotidiana das pessoas somente causaria medo e preocupação, o que de fato poderia atrair e piorar a infecção. ${ }^{50} \mathrm{Em}$ vez disso, argumentavam eles, era o pânico que tinha de ser combatido: "As pessoas que têm medo adoecem. Aqueles que ficam calmos e alegres podem passar ilesos por uma epidemia", declarou um influente médico britânico em 1919. ${ }^{51}$ Comunicar-se com o público por meio de jornais era algo também considerado com ceticismo por grande parcela da comunidade científica, o que significava que o debate público acerca da doença deveria ser evitado ao máximo possível. Outros ainda se aproveitavam da mídia não hesitando em criticar, nos maiores jornais suecos, a passividade tanto de seus colegas quanto das autoridades. ${ }^{52}$

Na Suécia, essa divisão de opiniões dentro da classe médica refletia-se, havia muito, na ausência de diretrizes consistentes por parte da autoridade nacional de saúde pública, a Real Diretoria Médica (Kungliga Medicinalstyre/sen). Dados os números crescentes de mortalidade, isto naturalmente fez com que as críticas mais ácidas aumentassem, porém as acusações de passividade foram rejeitadas com firmeza pela Diretoria, com o argumento de que "todas as recomendações têm de estar baseadas em evidências médicas inequívocas e não devem ser dadas somente com base em aparências". Conforme propõe Margareta Åman, provavelmente havia também motivos econômicos por trás da hesitação da Diretoria no que diz respeito às intervenções. Pedir-se às pessoas para evitar multidões, mercados e entretenimentos públicos era provavelmente afetar de modo

49 SFS, $1874,68, \S 35$.

50 TOMKINS, Sandra M. The failure of expertise, p.439, 443-445; ÅMAN, Margareta. Spanska sjukan, p.166.

51 Sir E. Napier Burnett em Daily Express, 1919. Apud: TOMKINS, Sandra M. The Failure of Expertise, p.440.

52 MÅNSSON, Jonas. Spanska sjukan: den medicinska professionens och samhällets reaktioner. Umeå: Universidade de Umeå, 2006, p.18ff. (Comunicação não publicada). 
negativo o comércio e os negócios da sociedade. ${ }^{53}$ Como conseqüência dessa ambigüidade oficial, nenhuma instrução geral alcançou o público antes do final de agosto, quando um pequeno panfleto, "Aviso e instruções para evitar a disseminação da influenza", foi distribuído pelos jornais. ${ }^{54} \mathrm{O}$ anúncio impresso foi originalmente uma iniciativa de alguns membros atentos da Sociedade Sueca de Medicina que estavam frustrados com o fato de que a autoridade nacional de saúde permanecia em silêncio frente a uma situação em que, na opinião deles, deveria ter agido. Em seis parágrafos curtos, aconselhava-se às pessoas a "evitar multidões e locais onde se aglomeravam muitas pessoas, como reuniões públicas, excursões, cinemas, bailes, teatros, igrejas, etc.", a lavar as mãos com freqüência e a manteremse longe de pessoas infectadas, "especialmente se estiverem tossindo". Além disso, dizia-se às pessoas que nenhum remédio disponível poderia preveni-las da doença e aconselhava-se que elas permanecessem em casa tão logo adoecessem. ${ }^{55}$ Enfim, essas recomendações foram oficialmente sancionadas pela Real Diretoria Médica "por pedido unânime", conforme declarado em edições impressas, posteriormente.

\section{Medidas preventivas e reativas em nível regional}

Em pesquisas anteriores acerca da resposta da comunidade à influenza epidêmica, as ações tomadas pela sociedade podem ser divididas em duas categorias: medidas preventivas e medidas lenitivas/reativas. O isolamento dos doentes, a quarentena dos infectados em potencial e a proibição de aglomerações públicas são elementos importantes da primeira categoria, enquanto o cuidado médico, a provisão de hospitais, o apoio doméstico e serviços funerários de emergência são exemplos dos esforços lenitivos mais pragmáticos da segunda categoria. ${ }^{56}$ Estes últimos, com freqüência, não eram produto de instruções nacionais, tampouco de iniciativas regionais de assistência durante a crise imediata, contudo foram de grande importância para quem estava acometido pela doença. ${ }^{57}$

Quando se consideram as ações das autoridades regionais de Västerbotten entre 1918 e 1920, fica óbvio que sua função mais crucial durante a pandemia era a de coordenar e distribuir os escassos recursos médicos

53 ÅMAN, Margareta. Spanska sjukan, p.168-169. Situação semelhante ocorreu na Grã-Bretanha; ver JOHNSON, Niall. Britain and the 1918-1919 influenza pandemic, p.130-141.

54 ÅMAN, Margareta. Spanska sjukan, p.165-170; MÅNSSON, Jonas. Spanska sjukan,18ff.

55 Real Diretoria Médica. (RDM). Råd och anvisningar angående influensan. Sept. 19, 1918; ÅMAN, Margareta. Spanska sjukan, p.160.

56 MARKEL, Howard; LIPMAN, Harvey B. et alli. Nonpharmaceutical Interventions, p.644; TOMKINS, Sandra M. The Failure of Expertise, p.443; JONES, Essylt W. Influenza 1918: disease, death and struggle, p.46-63; CROSBY, Alfred. America's forgotten pandemic, p.70-120.

57 TOMKINS, Sandra M. The failure of expertise, p.443, 452; ÅMAN, Margareta. Spanska sjukan, p.136-137; JOHNSON, Niall. Britain and the 1918-1919 influenza pandemic, p.131-141. 
na província. ${ }^{58}$ Isto foi feito pelo comitê executivo, a Diretoria Administrativa do Condado (Länsstyrelsen, doravante DAC), em cooperação intrínseca com as autoridades médicas responsáveis: o Oficial Chefe de Saúde, em nível regional, e a Real Diretoria Médica, em nível nacional. Quando as necessidades urgentes surgiam em um distrito a DAC alertava as autoridades médicas nacionais, que eram responsáveis por indicar o pessoal médico e por designá-lo para os distritos mais gravemente acometidos. Essa equipe extra, que contava com freqüência com jovens enfermeiras e estudantes de medicina voluntários, podia ser posteriormente transferida para outras localidades, onde houvesse maior necessidade, se assim decidisse a DAC. ${ }^{59}$

Era imensa a falta de pessoal médico com formação superior, e, de agosto de 1918 em diante, a DAC trabalhou duro em Västerbotten para prover de cuidados médicos os distritos mais afetados. O primeiro médico assistente foi enviado ao distrito rural de Dorotea, na porção afastada da costa, em 17 de setembro de 1918, tendo sido designado por quatro semanas. ${ }^{60}$ A necessidade desesperadora por um médico em um distrito remoto, onde o posto de Oficial de Saúde Distrital estava vago havia muito tempo, é descrita em uma carta do presidente do Comitê Executivo Municipal, datada de 11 de setembro de 1918:

Há três semanas tenho trabalhado do anoitecer até o amanhecer por causa da epidemia de espanhola. Todas as minhas enfermeiras e aqueles que me auxiliam ficaram doentes, com exceção de um último. E eu mesmo espero ficar acamado em breve, e, assim, aqueles que sobreviveram à doença estão incapacitados ou ainda não estão em condições de cuidar dos doentes e de supervisionar as providências a serem tomadas. ${ }^{61}$

Em Västerbotten, 12 dos 21 médicos assistentes que foram designados para a província entre setembro de 1918 e março de 1920, foram enviados para distritos com cargos vagos como o de Dorotea, principalmente na porção afastada da costa. Um grande número de enfermeiras, enfermeiras treinadas bem como enfermeiras assistentes com formação técnica, foi também designado nesse mesmo período e enviado aos distritos que necessitavam. Diversas fontes da época dão testemunho da pesada carga de trabalho e das muitas dificuldades com que se depararam esses homens e mulheres, jovens e inexperientes, em áreas onde o cuidado médico havia sido negligenciado por muito tempo. ${ }^{62}$ Em 1920, todo o pessoal extra foi

\footnotetext{
58 SFS, $1874,68, \S 35$.

59 Ver, por exemplo: Härnösand. Arquivo Regional de Härnösand. ACA. Decretos da Real Diretoria de Medicina DIlp:3, Dnr.109/44; Resolução Universitetskanslerns de 26 de outubro de 1918. In: BLOCK, Fr. Författningar m.m. angående Medicinalväsendet i Sverige omfattande år 1918, Stockholm: Svenska Tryckeriaktiebolaget, 1918, p.306. ÅMAN, Margareta. Spanska sjukan, p.54.

60 Arquivo Regional de Härnösand. AAD. Decretos da RDM 1908-1921 Dllp:3, Dnr.109/43.

61 Arquivo Regional de Härnösand. AAD. Cartas de Médicos de 1916-1923 Dillu:3, Dnr.288/36

62 ÖHMAN, Lennart, Hur sjukvården kom till norr, p.263ff.
} 
enviado para os distritos afastados da costa, principalmente durante a quarta e severa onda, em fevereiro e em março de 1920. Os grandes esforços a fim de fornecer cuidados médicos aos distritos afetados gravemente em particular não visavam principalmente evitar a disseminação da doença. $O$ pessoal extra era enviado para amenizar as necessidades mais urgentes em uma situação em que os recursos médicos eram limitados ao extremo, e, quando chegava a ajuda, na maioria das vezes a pandemia já vinha se manifestando havia algum tempo no distrito (Figura 7). Essa medida oficial deve ser classificada como sendo inteiramente reativa.

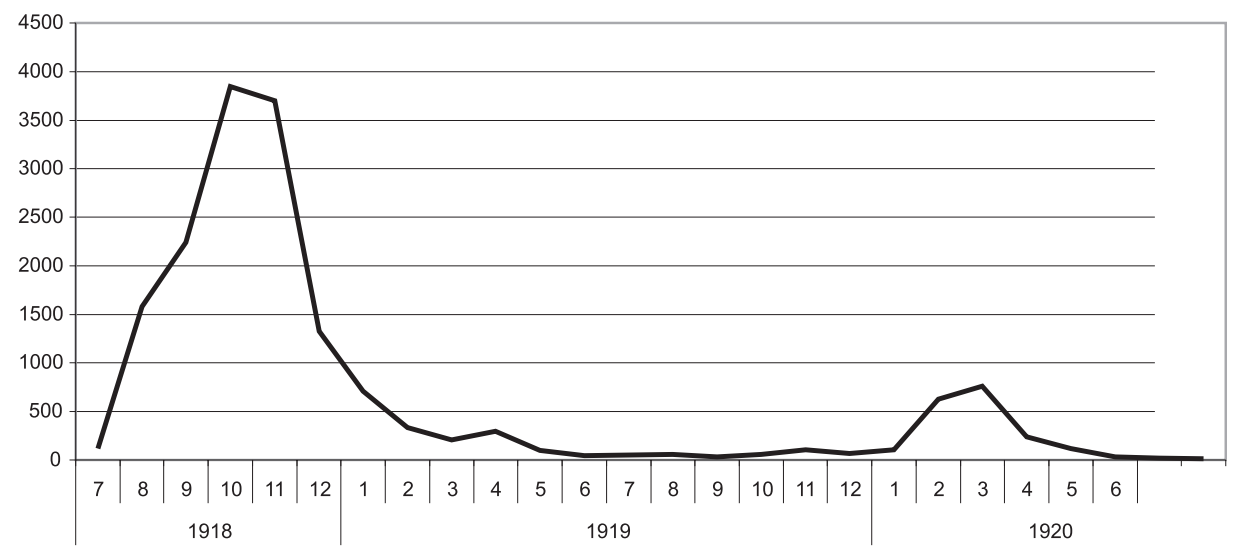

Figura 7

Fonte: Médico oficial chefe de saúde, Västerbotten, Relatórios Anuais de 1918, 1919 e 1920.

Outra importante função da autoridade regional durante a pandemia era promulgar um grande número de proibições de aglomerações públicas. Conforme prescrevia a estrutura oficial, a DAC tinha o dever explícito de promulgar os decretos considerados necessários para evitar a disseminação da doença. ${ }^{63}$ As proibições em Västerbotten seguiam o mesmo padrão bem conhecido de muitos outros contextos, na Europa e nos Estados Unidos, com ênfase nas atividades relacionadas ao entretenimento e ao lazer. Apresentações teatrais, cinemas e bailes estavam terminantemente proibidos, bem como "outras aglomerações públicas que provocam a concentração de multidões", ao passo que não se incluíam os serviços religiosos nas proibições. Um fato interessante é que no rascunho, escrito à mão, da primeira proibição o culto religioso público também estava mencionado entre

63 SFS, 1874, 68, § 35. As autoridades regionais não lidavam com tópicos relativos ao fechamento de escolas, pois estes eram considerados assuntos puramente municipais. 
as atividades vetadas, porém foi posteriormente riscado no manuscrito e cortado por inteiro da edição impressa do decreto. ${ }^{64}$ Os reais motivos desse ajustamento permanecem desconhecidos, mas não se pode descartar que ele se refira, em alguma medida, ao reflexo de uma duradoura relação entre saúde precária e hábitos de moralidade duvidosa. ${ }^{65}$ Teatros, cinemas e salões de dança podem simplesmente ter sido considerados mais "perigosos" do que as igrejas.

Entre outubro de 1918 e abril de 1920, promulgaram-se 14 proibições regionais em Västerbotten, conforme ordem das autoridades municipais nas freguesias afetadas: 13 proibições devido à influenza epidêmica e uma devido a uma eclosão grave de difteria ${ }^{66}$ Levando-se em consideração o momento no qual as proibições foram efetivadas, fica claro que também essas medidas - que se pretendiam preventivas - na realidade eram, por natureza, mais reativas. A primeira proibição foi promulgada pela supracitada freguesia de Dorotea e datada de 8 de outubro, período em que a pandemia já estava a todo vapor havia mais de um mês. ${ }^{67}$ Situação idêntica aconteceu em Byske, onde uma proibição foi promulgada em 11 de novembro, mês em que a morbidade notificada alcançou seu pico no distrito (Figura 4) ${ }^{68}$ Somente uma vez, em 27 de março de 1920, promulgou-se uma recomendação mais geral ao público, quando a quarta onda da influenza pandêmica atingia a província. Desta vez, pedia-se que, após a nova eclosão da influenza, as pessoas se abstivessem de freqüentar mercados, sessões nos tribunais e áreas com multidões. ${ }^{69}$ Também desta vez o aviso veio tarde. Ao final de março, a morbidade já havia alcançado seu pico em Västerbotten, com 764 casos em março de 1920, em comparação com 242 em abril do mesmo ano. ${ }^{70}$

\section{Medidas preventivas e reativas em nível local}

Em nível local, em Skellefteå, Byske, Bureå, Burträsk e Jörn, a devastadora pandemia de influenza de 1918-1920 surpreendentemente deixou poucos traços nos registros oficiais. ${ }^{71}$ Nos documentos municipais relativos a 1918-1920 da maior das freguesias, Skellefteå, não se encontra uma única referência que indique, de alguma maneira, que ocorreu uma pandemia

64 AAD. Proclamações Públicas, AlVa: 27-20, Proclam.149, 8 outubro de 1918.

65 EDVINSSON, Sören. Den osunda staden, p.81.

66 Arquivo Regional de Härnösand. AAD. Proclamações Públicas, Alva: 27-20, 1918-1920.

67 Stockholm. Arquivo Nacional. ADNM. Influensabyrån, relatórios especiais de 1918, Ell:2. Arquivo Regional de Härnösand. AAD. Proclamações Públicas, AlVa: 27-20, Prc.149, Oct.8, 1918.

68 Arquivo Regional de Härnösand. AAD. Proclamações Públicas, AlVa: 27-20, Prc.210, Nov.11, 1918.

69 Arquivo Regional de Härnösand. AAD. Proclamações Públicas, AlVa: 27-20, 27 de março de 1920.

70 Relatório Anual de 1918, OCS de Västerbotten, p.55.

71 TOMKINS, Sandra M. The failure of expertise, p.449. Situação similar aconteceu em alguns dos bairros de Londres, cujos registros tiveram que ser "espremidos" para que se encontrasse alguma evidência da pandemia existente. Ver também: ECHENBERG, Myron. 'The dog that did not bark', p.230. 
arrasadora. Os registros revelam um retrato detalhado das privações causadas pela falta de alimentos e pelos preços que subiam, das medidas locais tomadas para aliviar as pressões sobre a sociedade, assim como sobre os lares destituídos, mas a influenza espanhola permanece invisível. ${ }^{72}$ Esta completa ausência de referências à pandemia pode ser explicada, em alguma medida, pelos registros que foram perdidos pelo Comitê Executivo Municipal relativamente ao período mais crítico, o ano de 1918, porém é improvável que os registros que sumiram pudessem por si só responder por tal espantoso silêncio. Grande número de outras fontes, em Skellefteå, relativas a esse período foram também escrutinadas, inclusive os relatórios anuais dos Oficiais de Saúde Distritais, sem que se encontrasse evidência, de qualquer espécie, da reação da comunidade ou de intervenção em nível local. ${ }^{73}$ Os jornais locais, que seguiam de perto o os acontecimentos na região, não mencionavam quaisquer medidas oficiais tomadas entre agosto e dezembro de 1918, exceto por uma linha curta, no início de setembro, que declarava que se estava considerando o adiamento do semestre escolar. ${ }^{74}$ Além disso, as autoridades locais não fizeram nenhum pedido por pessoal médico extra nem para que a DAC promulgasse alguma proibição de aglomerações públicas.

A situação é idêntica nas quatro outras freguesias. Discutem-se nos registros municipais as privações e a crise de alimentos, mas não se têm evidências de nenhuma resposta, que seja digna de nota, por parte da comunidade em relação à crise de saúde provocada pela influenza. Porém, diferentemente de Skellefteå, o silêncio não foi completo acerca do que estava acontecendo, embora, nas fontes, as evidências sejam fragmentárias e nem sempre claras. Em Jörn, por exemplo, os registros de Socorro aos Pobres de 1920 dão testemunho da ajuda concedida a famílias e a indivíduos para quem o sofrimento durante a influenza espanhola tinha sido aparentemente uma porta de entrada para a pobreza. ${ }^{75} \mathrm{Em}$ janeiro e em fevereiro daquele ano, a freguesia foi gravemente afetada pela quarta onda da pandemia, que, ao longo daqueles dois meses, resultara em uma letalidade de aproximadamente 7\% na freguesia: 12 de 175 casos foram fatais. ${ }^{76} \mathrm{~A}$ despeito dessa convivência implacável com a influenza, o Oficial de Saúde Distrital estabelece em seu relatório anual de 1920 que "nenhum

72 Skellefteå. Arquivo da Municipalidade de Skellefteå. Arquivo Municipal de Skellefteå. (AMS). Comitê Executivo Municipal, A1:4, 1914-1918, A1:5, 1918-1922; Diretoria Municipal, A1:3, 1917-1920; Conselho Municipal A1:1 1918-1919, A1:2 1910-1925.

73 Arquivo Nacional. MAS. Comitê Executivo Municipal, All:1, 1918-1920; Comitê de Distribuição de Alimentos, A1:1, 1917-1918; F1:1, 1879-1924; Skelleftebladet, 1918-1920; ADNM. Influensabyrån, relatórios especiais de 1918, Ell:2; Relatórios Anuais do OSD de 1918-1920, Ella:14, 18, 22.

74 Skelleftebladet, 1918, Set 3, 10.

75 Arquivo Municipal de Jörn. Diretoria de Socorro aos Pobres, Al:1, 6 de março de 1920, § 4. Skellefteå. Arquivo da Municipalidade de Skellefteå; MARKLUND Göran. Sjukvården i Jörn. Jörn: Jörns hembygdsförening, 2002; Arquivo Nacional. ADNM. Relatórios Anuais dos Oficiais de Saúde Distritais, Ella:22, Jörn, 1920.

76 Arquivo Nacional. ADNM. Relatórios Anuais dos Oficiais de Saúde Distritais, Ella:22, Jörn, 1920 
assunto de saúde pública foi discutido neste ano no Comitê Executivo Municipal". ${ }^{77}$ Em Byske, a freguesia com a mais elevada morbidade notificada de influenza em 1918, a única referência à doença epidêmica nos registros municipais é um curto parágrafo, no início de janeiro de 1919, dizendo que o isolamento provisório havia sido preparado e enfermeiras extras haviam sido empregadas em duas localidades da freguesia. ${ }^{78}$ Neste caso, entretanto, as medidas extraordinárias não foram instigadas pela influenza, mas pela difteria. A freguesia era assombrada por uma epidemia local dessa grave doença que fez com que o DAC promulgasse a proibição de aglomerações públicas em 18 de janeiro de 1919. O Oficial de Saúde Distrital, Dr. Bjerner, trabalhou duro para dificultar a disseminação da doença e, sob seu comando, grandes esforços foram realizados para isolar os doentes. ${ }^{79}$ A impressão geral é de que, em todas essas comunidades rurais, epidemias recorrentes de difteria parecem ter dado fôlego a mais intervenções extensivas em nível local do que a influenza o fez. Quando se estudam os Relatórios Anuais dos Oficiais de Saúde Distritais, também se torna claro que o controle de doenças e a iniciativa de intervenções, ao menos em circunstâncias corriqueiras, estavam nas mãos do médico local e não eram assunto para as autoridades municipais. ${ }^{80}$

Em Bureå e em Burträsk, a presença da influenza pandêmica se expressa principalmente por meio de proibições de aglomerações públicas. Em abril de 1919, o chefe do Comitê Executivo Municipal de Bureå foi à DAC requisitar uma proibição geral, "pois eclosões graves de febre escarlate, difteria e influenza espanhola" apareceram na principal localidade da freguesia. ${ }^{81}$ Em Burträsk, o Comitê Executivo Municipal promulgou proibição similar, porém desta vez sem envolver as autoridades regionais. O Relatório Anual do Oficial de Saúde Distrital dá testemunho da grave situação na freguesia rural:

A doença cresceu gradualmente em força e tornou-se mais grave, com diversas fatalidades, até atingir seu pico em outubro e em novembro, aparecendo sob uma forma dificílima, com numerosas mortes devido à pneumonia (...). ${ }^{82}$

A partir 12 de outubro de 1918 e até novo comunicado, proibiram-se todas as espécies de entretenimento e aglomerações públicas, e requisi-

77 Arquivo Nacional. ADNM. Relatórios Anuais dos Oficiais de Saúde Distritais, Ella:22, Jörn, 1920.

78 Skellefteå. Arquivo da Municipalidade de Skellefteå. Arquivo Municipal de Byske. Comitê Executivo Municipal, Al:5, 29 de Jan.,1919.

79 AAD. Proclamações públicas, AlVa: 27-20 Prc.19, 1919; Arquivo Municipal de Byske. Comitê Executivo Municipal, El:3 Carta de um Oficial de Saúde Distrital, de19 de Janeiro de 1919. Skellefteå Municipality Archive; Arquivo Nacional. ADNM. Relatórios Anuais dos Oficiais de Saúde Distritais, Ella:18, Byske 1919.

80 Arquivo Nacional. ADNM. Relatórios Anuais dos Oficiais de Saúde Distritais de 1918-1920, Ella:14, 18, 22.

81 Arquivo da Municipalidade de Skellefteå. Bureå Municipal Archive. Municipal Executive Committee, All:1 Supplements, Apr.15, 1919

82 Arquivo Nacional. ADNM. Relatórios Anuais dos Oficiais de Saúde Distritais, Ella:14, Burträsk, 1918. 
tou-se que as pessoas evitassem aglomerações. ${ }^{83}$ Considerando-se que a epidemia já estava a todo vapor, também essa tentativa de reduzir a disseminação da doença deve ser classificada como uma medida reativa em vez de preventiva. Porque nas fontes não se discutem as razões que se ocultam por trás dessa decisão, permanece desconhecido se o Comitê realmente pensou que a disseminação da doença poderia ser reduzida ou se essa intervenção era uma maneira de mostrar que a ação estava sendo tomada em uma situação em que pouquíssimo poderia ser feito. Em circunstâncias difíceis, os administradores locais agarraram-se a uma das poucas medidas disponíveis que poderiam ser tomadas em nível local. O fato de que se pediu às pessoas da esparsamente povoada freguesia de Burträsk, onde não havia sequer um cinema, que se abstivessem de todos os tipos de entretenimentos públicos e que evitassem formar multidões sugere que a proibição não foi formulada principalmente com referência às necessidades locais. Isto demonstra, ademais, que as poucas recomendações nacionais estavam consideravelmente mais bem adaptadas à situação nas cidades do que ao contexto social rural específico.

Quando a quarta onda chegou, em 1920, e o decreto geral foi promulgado, aconselhando às pessoas que evitassem freqüentar mercados e áreas povoadas, este não foi tão prontamente acatado pelos administradores locais de Burträsk. Desta vez, a situação era diferente. A influenza ainda não estava na freguesia, e apenas algumas semanas antes da feira de primavera, o Comitê Executivo Municipal não estava pronto para forçar quaisquer restrições impositivas sobre os moradores:

Visto que o Oficial de Saúde Distrital não estava ciente de um único caso da doença dentro dos limites da freguesia e dado que os membros desse comitê tinham conhecimento de que a feira vindoura era normalmente freqüentada por poucas pessoas de outras freguesias e de que havia um risco muito pequeno de algum contágio entrar na freguesia por essa via, o comitê não estava preparado para tomar qualquer iniciativa no sentido de medidas a serem propostas. ${ }^{84}$

A mudança de atitude do Comitê Executivo em relação à virtual utilidade de uma proibição pode servir de exemplo de como os potenciais benefícios das medidas de saúde pública preventivas eram considerados em detrimento de outros interesses da sociedade. Durante uma epidemia avassaladora na qual as pessoas estavam morrendo, inconvenientes para as populações e conseqüências econômicas negativas não eram a preocupação principal das autoridades locais. Entretanto, quando não se apresentava nenhuma

83 Arquivo da Municipalidade de Skellefteå. Arquivo Municipal de Burträsk. Comitê Executivo Municipal, Al:4 19161923, 12 de out. de 1918, § 101.

84 Arquivo da Municipalidade de Skellefteå. Burträsk. Arquivo Municipal. Comitê de Saúde Pública. Al:1, March 6 1920. 
ameaça aparente, as prioridades eram outras. Porque cuidar de outros pode ser, em certa medida, "segurança própria contra a possibilidade de se acabar na mesma situação que eles", os administradores locais estariam mais inclinados a tomar ações radicais contra a grave pandemia se eles próprios, ou seus entes queridos, estivessem sob o risco imediato de tornarem-se infectados. ${ }^{85}$ Este é um fator que, ainda hoje, muito provavelmente comanda a prontidão das comunidades em responder a uma crise.

Questionar se o fechamento de escolas seria um meio eficiente de impedir a disseminação da influenza no caso de uma nova pandemia tem sido um tópico recorrente em pesquisas recentes. ${ }^{86}$ Discussão similar aconteceu também ao longo da pandemia de 1918-20 na Suécia. Aqueles que advogavam essa idéia propuseram que, para limitar a disseminação da doença, o início das aulas, marcado para setembro de 1918, deveria ser adiado até a epidemia diminuir. O fechamento de escolas havia sido uma resposta utilizada com freqüência para outras epidemias locais recorrentes como, por exemplo, de difteria, de sarampo ou de febre escarlate. No que diz respeito à influenza, contudo, questionava-se sua utilidade. Considerando-se a acelerada disseminação da doença, também as crianças estavam sob o risco de pegar a doença fora da escola, argumentavam aqueles que eram contrários à idéia. ${ }^{87}$ Argumentos semelhantes já haviam sido apresentados ao longo da pandemia de influenza de 1889-90. Um certo Dr. Friman, oficial de saúde distrital de Vänersborg, estava realmente cético quanto a esse tipo de medida preventiva:

Normalmente, o fechamento de escolas não tem as conseqüências desejadas, pois o clero e as Diretorias Escolares não permitem que as escolas permaneçam fechadas pelo tempo necessário e, visto que a doença também se espalha, enquanto as escolas estão fechadas por meio da mistura de crianças desocupadas com outras da vizinhança, mesmo quando estão infectadas, e isto não pode ser impedido por nenhuma proibição. ${ }^{88}$

Não se promulgou nenhuma diretriz impositiva e, em setembro de 1918, a Real Diretoria de Medicina declarou que as decisões sobre o fechamento de escolas deveriam ser um assunto de cada comunidade local. Havia, contudo, a recomendação de que se adiasse o início do semestre letivo, até quatro semanas após a eclosão, se uma epidemia grave ainda estivesse acontecendo no final das férias de verão, em setembro. ${ }^{89}$

85 KRISTOV, Lorenzo; LINDERT Peter. Pressure groups and redistribution. Journal of Public Economics, v.48, n.2, p.146-147, 1992.

86 Ver: BARNES, Belinda. How much would closing schools reduce transmission during an influenza pandemic Epidemiology, v.18, n.5, p.623-628, 2007.

87 MÅNSSON, Jonas. Spanska sjukan, p.18

88 DHO. Universidade de Linköping, Relatório Anual de 1890, DHO, Vänersborg.

89 RDM. Råd och anvisningar, 19 de set. de 1918. 
Em todas as cinco freguesias rurais estudadas, as escolas foram fechadas durante a pandemia, porém as fontes sugerem que, também nesse caso, estamos lidando com uma medida reativa, em vez de preventiva. As escolas não eram fechadas tendo a prevenção como razão principal, mas sim porque a epidemia estava assolando tanto em meio aos alunos quanto aos professores..$^{90} \mathrm{Em}$ Skellefteå, os registros da Diretoria Escolar mencionam que as aulas foram canceladas por até 5 ou 6 semanas devido à ausência do professor e que situação semelhante ocorria em outras freguesias. ${ }^{91}$ Logo, a ocasião dos fechamentos variava de escola para escola, porém estes parecem ter sido mais freqüentes em outubro e em novembro, quando a pandemia encontrava-se em seu pico. ${ }^{92}$ Conforme já mencionado, discutia-se o adiamento do semestre letivo, mas, por razões desconhecidas, essa idéia não foi posta em prática e as escolas deram início às aulas na data previamente estabelecida: 14 de setembro. ${ }^{93}$

\section{Medidas não-oficiais e esforços voluntários}

É importante ter em mente que o silêncio incomum nos registros oficiais não significa necessariamente que essas comunidades estivessem inteiramente passivas durante a pandemia. Os documentos remanescentes das várias corporações municipais apenas refletem os assuntos que eram levados às reuniões e normalmente não nos dizem muito sobre o que acontecia fora de seu alcance. Um curto parágrafo dos anais do Comitê Executivo Municipal em Burträsk, todavia, chama à atenção, em maio de 1919, para o fato de que a resposta social à pandemia não se reduzia necessariamente às corporações municipais oficiais. Nesse caso, requisitava-se ao comitê que ressarcisse uma jovem mulher porque ela trabalhara como enfermeira para uma família gravemente acometida pela influenza. A requisição foi negada com o argumento de que, sendo este o assunto, não cabia à municipalidade. Em vez disso, a mulher foi encaminhada aos contribuintes da comunidade da vila à qual a família doente pertencia, os quais, de acordo com o comitê, em diversos outros casos tinham pagado pelos cuidados às famílias atingidas com recursos comuns ${ }^{94}$ Visto que pesquisas anteriores demonstraram a presença de um forte senso de comunidade no nível das vilas na Västerbotten rural, particularmente em épocas de crise, não era de se surpreender que se encontrassem evidências deste tipo. Uma característica distintiva dessa parte da Suécia era a presença de organização tradicional

90 C.f. TOMKINS, Sandra M. The failure of expertise, p.448

91 Arquivo Nacional. Arquivo da Freguesia de Skellefteå. Minutas da Diretoria Escolar, 26 de outubro de 1918, 24 de jan., 1919; Ver também ADNM, Relatórios Anuais dos Oficiais de Saúde Distritais, Ella:14, 1918

92 Arquivo da Municipalidade de Skellefteå. Registros Escolares, 1918.

93 Skelleftebladet, 10, 3 de setembro 1918.

94 Arquivo da Municipalidade de Skellefteå. Arquivo Municipal de Burträsk, Commitê Executivo Municipal, A14, May 3, 1919, § 44 . 
e informal entre os contribuintes de cada uma das vilas rurais, que servia para a tomada de decisões autônomas, em nome dos vizinhos. Na vasta freguesia de Skellefteå, onde grandes distâncias muitas vezes impediam uma administração efetiva, era comum incumbirem-se as corporações locais também do cumprimento de diferentes deveres municipais. Por exemplo, as comunidades de vilas lidaram com o Socorro aos Pobres durante a maior parte do século XIX e ao longo da crise de alimentos na década de 1830 e na década de 1860, a distribuição e a supervisão de alimentos no nível da vila foram um componente crucial do gerenciamento oficial da crise. ${ }^{95}$ Aparentemente, essa dependência de medidas não-oficiais, que infelizmente permanece invisível nas fontes com demasiada freqüência, ainda sobrevivia à época da pandemia de 1918-20. ${ }^{96}$ Esse argumento é ainda mais reforçado por uma carta, datada de 15 de outubro de 1918, da DAC às comunidades locais de Västerbotten. Nessa situação extraordinária, em que as necessidades excediam em muito os recursos disponíveis, as autoridades oficiais aparentemente demonstravam também grande confiança na solidariedade mútua e em medidas não-oficiais. Recomendava-se às municipalidades que reunissem um conjunto de voluntários dispostos a assistir as famílias que estavam sofrendo, nos cuidados básicos e tarefas domésticas, incluindo-se tomar conta de seu gado e de sua fazenda. Não se sabe se essa recomendação foi alguma vez posta em prática nessas comunidades rurais, pois os registros permanecem em silêncio também quanto a esse tópico. ${ }^{97}$

\section{Conclusões}

A vivência rural da pandemia de influenza de 1918-20 foi diferente daquela nas vilas e nas cidades. Embora seja necessário mais do que o presente estudo para responder a essa questão de grande projeção, resta claro que diferentes condições e recursos básicos dão fôlego a diferentes respostas sociais. Nessas cinco comunidades, poucas iniciativas oficiais foram tomadas para evitar a disseminação da doença ou para mitigar suas conseqüências, e a presença da influenza pandêmica é quase invisível nos registros municipais. Este é um padrão claramente distinto daquele apresentado em diversos estudos recentes acerca de grandes cidades norte-americanas onde as intervenções na saúde pública foram consideravelmente mais freqüentes.

95 ENGBERG, Elisabeth. I fattiga omständigheter: fattigvårdens former och understödstagare i Skellefteå socken under 1800-talet. Umeå: Base de Dados Demográficos, 2005, p.95-114

96 ENGBERG, Elisabeth. I fattiga omständigheter, p.322-324.

97 Arquivo Municipal de Byske. Comitê Executivo Municipal, El:3, 15 de out. de 1918. 
Provavelmente há diversas explicações plausíveis para esta resposta esparsa e reativa da comunidade à devastadora pandemia. Uma delas é provável de ser encontrada no sistema de saúde público precariamente desenvolvido, com uma organização que não havia mudado desde meados do século XIX. À época da eclosão da pandemia de influenza de 1918-20, todos os assuntos concernentes à saúde pública nas cinco comunidades estudadas eram tratados por meio dos comitês executivos das municipalidades, ao lado de uma variada gama de outras importantes responsabilidades municipais. Em 1918, assuntos de saúde pública também competiam com todos os assuntos urgentes relacionados à crise de alimentos então vigente, às privações em geral de uma época de guerra e a uma economia tensa. As vilas, com seus Comitês de Saúde obrigatórios estavam, sem dúvida, providas com uma organização consideravelmente mais adequada para ordenar medidas efetivas quando se requeria intervenção.

A escassez de medidas efetivas nessas comunidades deve também ser observada com vistas à legislação nacional, que falhou ao tentar dar instruções claras sobre como lidar com uma epidemia dessa natureza. Delineadas até 1875, as leis de Controle de Saúde Pública e de doenças adequavam-se primeiramente aos surtos potenciais de cólera e a epidemias de disseminação mais controlada do que a influenza. Ao lidar com uma eclosão dessa magnitude, mecanismos antes úteis, como o controle de fronteiras, o isolamento e a desinfecção, tornaram-se inadequados e difíceis de serem utilizados. A discordância pública entre os profissionais e a falta de iniciativa em nível nacional muito provavelmente também impediram a ação local. As municipalidades locais possuíam grande liberdade para decidir se as intervenções públicas eram desejáveis ou não, e, dado o conselho ambíguo das autoridades nacionais, deve ter sido difícil decidir se restrições impositivas às pessoas realmente faziam bem ou mal. Situação semelhante esteve presente na Grã-Bretanha, e a historiadora Sandra Tomkins argumenta de modo convincente que essa falta de consenso entre as autoridades de saúde e aqueles que fazem as políticas públicas foi um das razões para a resposta muito pacífica da saúde pública à pandemia de 1918-20 naquele país. ${ }^{98}$ Outra importante observação é a de que a utilidade em potencial das políticas e das recomendações nacionais pode diferir de um contexto social para outro. Estratégias preventivas formuladas relativamente a vilas e a cidades podem tornar-se difíceis de serem implementadas em áreas rurais esparsamente povoadas com condições básicas diferentes, recursos diferentes e um modo de vida diferente.

Em particular, o contexto socioeconômico de 1918 - a escassez de alimentos que ainda pressionava, a inquietação política e as privações

98 TOMKINS, Sandra M. The Failure of Expertise, p.445, 449. 
duradouras de uma época de guerra - também se destaca como uma explicação plausível para as poucas iniciativas oficiais tomadas relativamente à pandemia. À época da eclosão, em 1918, as autoridades locais já tinham as mãos ocupadas com as tentativas de lidar com a distribuição de alimentos, políticas de regulamentação de preços e com as crescentes necessidades da população, dentro de uma economia tensa. Em uma situação assim, uma eclosão de influenza pandêmica pode ser percebida com facilidade justamente como sendo mais um tormento associado à guerra e às suas privações. Embora isto não possa ser verificado nas fontes, deve-se considerar como sendo provável que esse contexto social em particular tenha afetado a prontidão das autoridades em agir, mas isso talvez tenha sido provocado também pelas expectativas dos indivíduos relativamente às autoridades em uma época em que o povo estava acostumado a sofrer. Também em um país neutro como a Suécia, os resultados da pandemia de 1918-1920 e a resposta social a ela permanecem intrinsecamente ligados à Primeira Guerra Mundial e localizam-se no contexto de uma época de guerra.

Pode-se fazer outras perguntas no que diz respeito às responsabilidades e aos papéis dos diferentes atores em nível local. Durante pandemias, o Oficial de Saúde Distrital desempenhou um importante papel na comunidade local tanto como conselheiro das autoridades locais quanto como um oficial do estado responsável por fornecer relatórios e estatísticas, mas também como aquele que fornecia cuidados de saúde aos indivíduos acometidos pela doença. Além disso, uma possibilidade que tem sido considerada é a de que essa eclosão da doença epidêmica pode também ter sido vista como um assunto primordialmente relativo à classe médica e, como tal, como algo que não requeria qualquer atenção imediata das corporações municipais. Em circunstâncias normais, era o Oficial de Saúde Distrital que normalmente lidava com o controle de doenças, e não é improvável que os administradores locais tivessem hesitado em interferir se não fossem abertamente ordenados a fazê-lo. Por outro lado, no distrito remoto de Dorotea, onde nenhum profissional médico estava disponível à época da eclosão, o Comitê Executivo Municipal teve que tomar a iniciativa e organizar as medidas de cuidado e de assistência. No entanto, as fontes também indicavam a presença de outros sistemas, não-oficiais, de ajuda, em nível local, durante a pandemia, os quais se baseavam em auxílio e assistência mútuos entre vizinhos e dentro das comunidades das vilas. As autoridades municipais com freqüência tiravam vantagem dessa maneira tradicional de se lidar com as dificuldades durante as primeiras crises e, no século $X X$, ela ainda parecia ser parte intrínseca do gerenciamento de crises em áreas rurais.

A experiência com pandemia de 1918-1920 por parte dessas comunidades é também um lembrete das consideráveis dificuldades associadas à implementação de intervenções eficazes durante uma pandemia dessa 
natureza. Tais situações requerem ação corajosa e decisiva, medidas úteis, bem como informação boa ao extremo, já que o momento certo é um dos fatores mais críticos na mitigação eficaz da disseminação da doença. A partir de uma perspectiva do século XXI, é fácil descartar a resposta do século XX à influenza como sendo inadequada, assim como ineficaz. Todavia, com facilidade se esquece de que, não se tendo acesso às técnicas de monitoramento modernas ao longo do curso dos eventos e sob grande pressão, sem se saber o que viria a seguir, é extremamente difícil avaliar a situação e tomar decisões "corretas". Comparadas a um presente complexo, é importante que as vantagens estratégicas do entendimento posterior dos eventos sejam consideradas tanto por historiadores que tentam entender 0 passado quanto pelos responsáveis por fazer o planejamento de políticas públicas com vistas a um futuro desconhecido. 